\title{
梁の位置の変化と内部手先数の増加からみた 朝鮮多包系建築の斗栱形式の変遷について
}

\section{1. 序}

高麗末〜李朝の木造建築は，斗栱を疎組とするものと 詰組とする様式に大きく分けられる祀。このうち詰組と する様式は，これまで日本語の論文では「唐様」「詰組 系様式」と呼ばれ，韓国では「多包系（式」，共和国で は「包式」とされる祀もものであり，以下本稿では韓国の 用語に従い「多包系建築」とする。この多包系建築は元 の建築が伝来して成立したものと考えられ祽3，国風化さ れながら李朝末に至る様式である。そして，その時代的 な変化は主として斗栱各部にみられる裆。

この斗栱形式の変遷に関する従来の研究としては，藤 島亥治郎博士によって擬似尾垂木社 5 形の変化および 「手先の形成的単化と装飾的復雑化」が指摘され，さら に，杉山信三博士は「李朝初期」までを中心に多包系建 築の体系的な研究を行うとともに「李朝中・末期」にお ける斗栱各部の形式の変化を指摘している。以上に続く 研究の主なものとして，尹張炇博士は『韓国建築史』の なかで斗栱形式の変化に言及しており，鄭寅國博士は多 包系建築を「前期・中期・後期様式」に分けてその間の 差異点を指摘している。また，金正基博士も斗栱形式の 時代に伴う変化に注目しており，関口欣也博士も多包系 建築の系統を論じるなかで斗栱形式の変化に触れてい る茫。

しかしながら，これら従来の研究では研究の中心は李 朝の前半までにおかれており，特に李朝の後半一壬辰 乱非 (文禄・慶長の役) 以降については変化の傾向を指 摘するにとよ゙まっている観がある。したがって，いまだ 李朝末に至るまでの斗栱形式の変遷が体系的に把握され ているとは言い難い。関野貞博士の指摘哣8もあるように, 李朝の後半に朝鮮建築は独自の変化をしていると考えら れ，この時期までも含めた斗栱形式の変遷を明らかにす る必要がある。

本稿は，李朝末までの多包系建築の斗栱形式の変遷を 体系的に把握することを目的として，まず，斗栱に組み 込まれた梁の位置の変化および建物内部にあらわれる斗

* 東京工業大学 研究生

(昭和 59 年 6 月 6 日原稿受理日,昭和 60 年 1 月 11 日改訂原稿受理日, 討論期限昭和 60 年 8 月末日)

\section{正会員中西章*}

栱の手先数の増加に着目し，この点から斗栱形式の変遷 をあきらかにしようとするものである。

梁の位置の変化はこれまでまったく触れられていない が，斗栱内部の手先数の増加との関連が考えられ，また， 斗栱の他の部分の変化とも関連が認められるものであ り ${ }^{\text {社 }}$ ，多包系建築の斗栱形式の変遷をみる上で重要な要 素である。また，斗栱内部の手先数の増加については杉 山信三博士・尹張禜博士によってすでに指摘されている が济10，さらに詳しい検討が必要である。

なお，本稿では高麗末から李朝末までの多包系建築の 遺構のうち，建築年代を知ることができる表 1 にあげた 100 棟䄄 を対象にまず考察をすすめ，その後に建築年代 があきらかでない建物についての考察を加えることにす る。

\section{2. 梁の位置の変化}

図 1 のように，多包系建築では柱上斗栱に梁が組み込 まれている。本稿では,この梁の斗栱に対する位置(高さ) を，斗栱外部のはかり时木（図 1 で*印をした时木;以 下単に，はかり时木という）の位置を基準としてみてゆ <部。

はかり肘木と梁の位置関係によって，多包系建築の斗 栱は以下の 3 つの形式に分けることができる。第 1 の形 式は図1のように梁とはかり肘木が同じ位置にある形式 であり，梁は斗栱外部にそのまま突出し，大きな三角形 の梁頭になることが多い。この形式を以下「梁 0 型」と する。

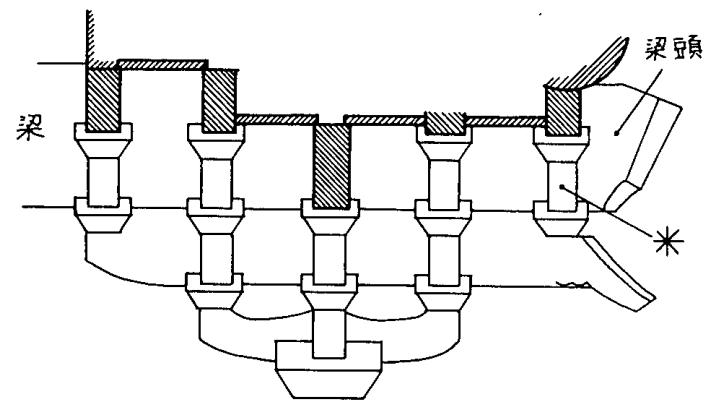

図 1 釈王寺応真殿 斗栱 (梁 0 型)

(藤島亥次郎「朝鮮建築史論 其五」插図をもとに，写真により 一部修正して作図) 


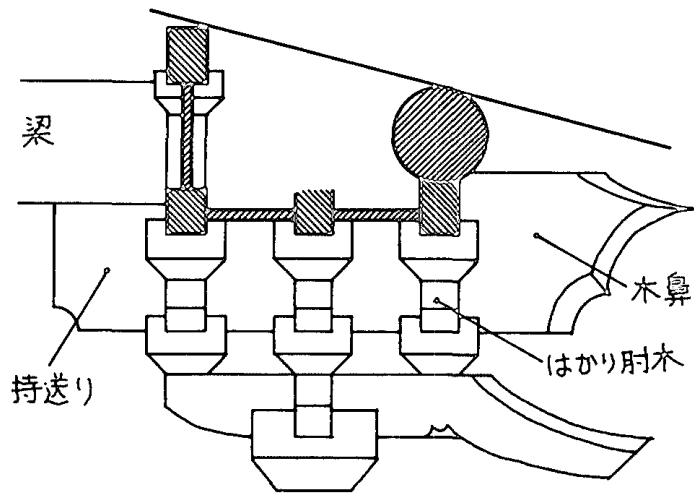

図 2 開城南大門 斗栱 (梁 1 型)

（関野貞『韓国建築調亘報告】挿図をもとに作図）

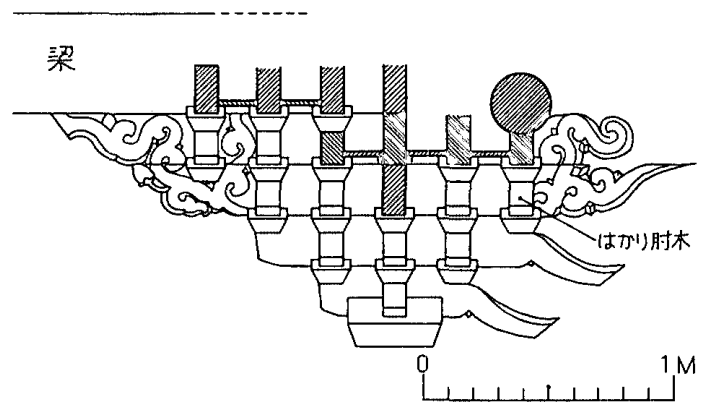

图 3 昌徳宮敦化門 斗栱 (梁 2 型)

(『A울 (ソウル) 特別市史古躀編』挿図をもとに作図)

第 2 の形式は, 図 2 のように梁がはかり肘六の位置よ りも 1 段上に組まれる形式である。はかり时木の位置に は外部で木鼻, 内部で梁の持送りとなる材を用いる。こ の形式を以下「梁 1 型」と呼ぶ。

第 3 の形式は図 3 のように，「梁 1 型」よりも梁がさ らに上に組まれ，はかり肘木の位置よりも2 段上にある 形式である。以下，「梁 2 型」とする。

表 1 の「梁の位置」は各建物の斗栱を以上の 3 つの形 式に分類したものである。

3 形式のうち, 最も古くからみられるのは「梁0型」 である。多包系建築の木造の遗構のうち最古のものであ る心源寺普光殿（1374：図 4) がこの形式となる。また, 「梁 1 型」も古くからみられる形式で，「梁 0 型」よりや や遅れるが，高麗未ないしは李朝の最初期の遺構である 凰停寺大雄殿 (高麗末・李朝初) や開城南大門 (1394: 図 2 ) ですでにみられている"13。このように，高麗圭・ 李朝の最初期からの古い多包系建築の斗栱は「梁 0 型」 と「梁 1 型」であった。

また，「梁 2 型」は以上の 2 型式よりも遅れ，15世紀 後半に平塨普通門 (1473：図6) 上層で初めてみられる。

以上のように，梁の位置からみた 3 つの形式は 15 世 紀後半に出揃ったが, 表 1 からそれぞれの形式が用いら れる例数 ${ }^{\ddagger 14}$ をると壬辰乱を境として大きな変化がみ られる。壬辰乱の以前には「梁 0 型」が 18 例中 10 例と 過半数を占めているのに対し,「梁 1 型」は 5 例であり「梁
0 型」の半数にとどまっている。これに対し壬辰乱の後 には，17 世紀の前半ですでに「梁 1 型」がソウル文廟 大成殿（1602）・昌慶宮明政殿（1616）をはじめとして 14 例を数えるのに対し，「梁 0 型」は金山寺大寂光殿 （1635）の1例だけとなる ${ }^{* 15}$ 。さらにこの傾向は李朝 の圭まで続き，19 世紀・20 世紀でも「梁 1 型」が 21 例 に対し「梁 0 型」は 3 例にとどまっている。すなわち, 梁の位置からみた桑朝圭の斗栱の中心形式として「梁 1 型」が指摘でき, この形式は壬辰乱の後に大きく普及し たといえる。

なお，「梁 2 型」は 15 世紀後半にあらわれて以降， 17 世紀に比較的多数の例がみられるが，19 世紀以降には まったくみられなくなる。

\section{3. 头洪队部の季先致の增加}

多包系建築には斗栱内部の手先数が外部よりも多くな る斗栱があることが知られている社。本稿では，この 内外の手先数の差を（内部の手先数一外部の手先数）で あらわすことにする。すなわち，図 4 のように内部 3 手 先・外部 3 手先で内外の手先数が同じときには，(内部 の手先数-外部の手先数）は 0 となり，以下このような 形式を「手先数 0 型」と称する。内部の手先数が外部よ りも多い場合も同様で,「手先数 1 型」「手先数 2 型」と 呼ぶことにする。表 1 の「手先数の差」は各建物の斗栱 を以上の形式によって分穎したものである。

心源寺普光殿 (1374：図 4) - 釈王寺応真殿（1386： 図 1 ) の高麗圭の両建築, および鳳停寺大雄殿 (高麗圭・ 李朝初)・開城南大門 (1394：図 2) など高麗末ないし は李朝の最初期の建物の斗栱はいすれれも「手先数 0 型」 であり，この形式が多包系建築の斗栱の古くからの形式 である。

内部の手先数が外部よりも多い斗栱は, 15 世紀の後 半に開心寺大雄殿（1484：図5）ではじめてみられる。 開心寺大雄殿の斗栱は外部 2 手先に対して内部は 3 手先 となっており，「手先数 1 型」である。さらにすすんで 壬辰乱の後には「乎先数 2 型」がみられるようになる。

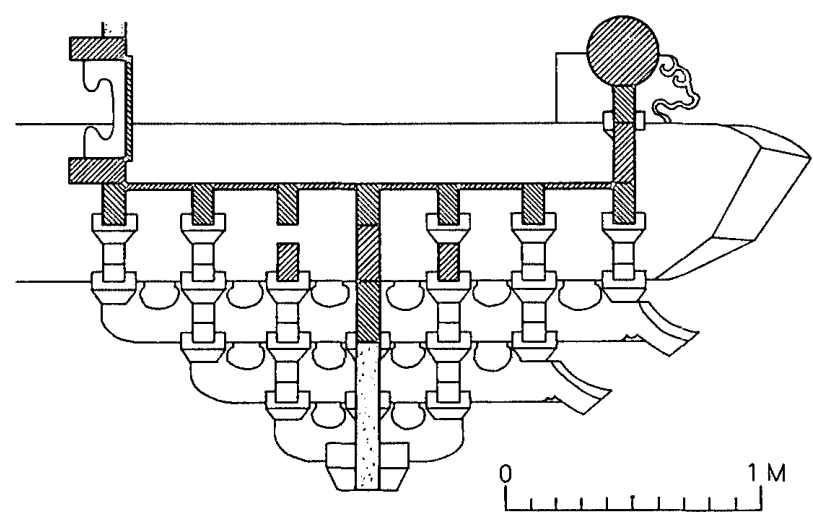

圆 4 心源寺普光殿 斗栱 (手先数 0 型)

（杉山信三『朝鮮建築史研究報告 第 2 冊」插図をもとに作図） 


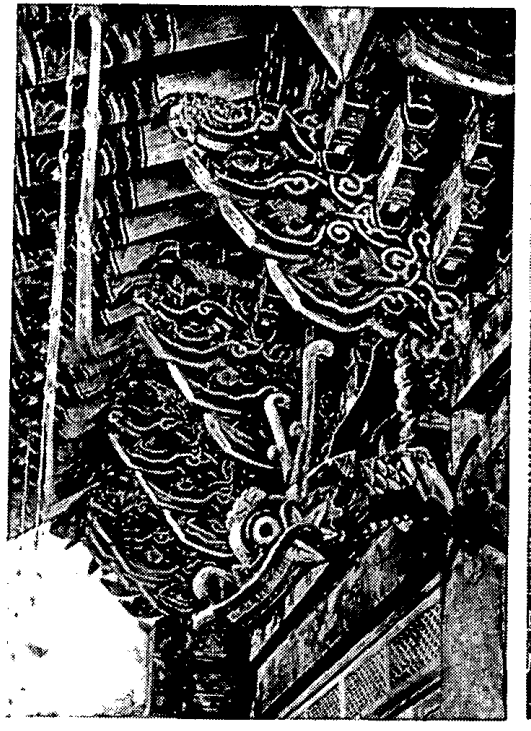

外部

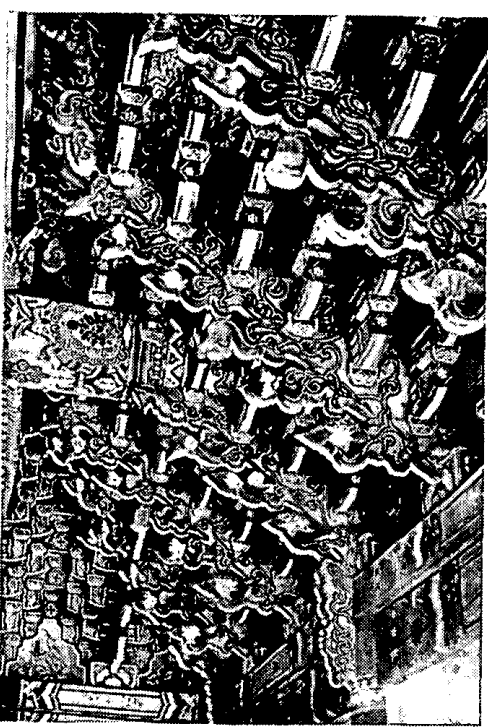

内部

写真 1 乾鳳寺大雄殿 斗栱

(「朝鮮古蹟図譜 十二」なより)

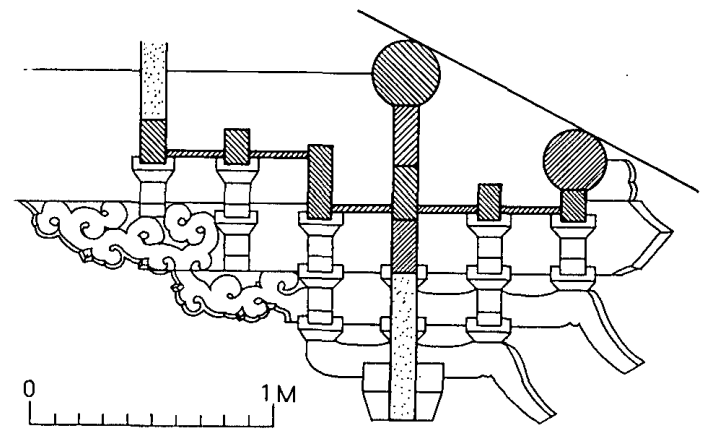

図 5 開心寺大雄殿 斗栱 (手先数 1 型)

(杉山信三「朝鮮建築史研究報告 第 2 冊」挿図をもとに作図)

伝燈寺大雄殿（1621）が最初の例であり, 斗栱は外部 2 手先に対して内部は 4 手先となる。また,「手先数 3 型」 は李朝末の乾鳳寺大雄殿（1879：写真 1) でみられる。 斗栱は外 3 手先に対して内部は 6 手先である。このよう に, 内部の手先数を外部よりも多くすることは 15 世紀 の後半から行なわれるようになり，時代を経るに従って 「手先数 3 型」までがあらわれる。

また，内部の手先数が多い斗栱が用いられる例数を表 1 からみると, 以下のような変化がみられる。壬辰乱以 前には前述の開心寺大雄殿と長安寺四聖殿 (李朝初) 上 層のわずか 2 例でこのような斗栱がみられるにすぎな い。これに対し壬辰乱の後になると昌徳宮敦化門 (1608) ・青谷寺大雄殿（1613）をはじめ 17 世紀前半だ けで「手先数 1 型」が 11 例みられ，「手先数 0 型」の 10 例とほぼ同数になる。さらに, 李朝の末-19 世紀以降 には，ほとんゼすべての斗栱は「手先数 2 型」「手先数 3 型」も含めて, 斗栱内部の手先数が外部よりも多い斗 栱となっており，逆に古くからの形式である「手先数 0 型」はほとんどみられなくなる。

すなわち, 内外手先数の差からみた李朝 末の斗栱形式としては内部の 手先数が外 部よりも多い斗栱が指摘でき，この形式 は15 世紀後半にあらわれ, 壬辰乱の後に 広く普及したものである。

4. 梁の位置の変化と内部手先数の 增加 との関係

柱上斗栱には梁が組み込まれており，斗 栱は内部でその梁を持送っている。そこで, 斗栱内部の手先数が外部の手先数に対して 増加することと, 斗栱に対する梁の位置と の間の関係が注目される。次に，この両者 を組み合せて, たとえば「梁1型」であり， かつ「手先数 0 型」の斗栱を「1-0 型」の斗 栱と表して, 両者の間の関係を考察するこ とにする。表 2 はそれぞれの組み合せにつ いて，もっとも早くみられる建物を示して いる。

現存最古の遺構である心源寺普光殿 (1374: 図 4) の 斗栱は「0-0 型」である。また，表 1，2 から「1-0 型」 の斗栱も高麗末ないし李朝の最初期からみられ, この 2 つの形式が多包系建築の古くからの形式である。

この古くからの 2 形式と異なる形式としてはまずあら われるのが「2-0型」と「1-1型」であり，いずれも 15 世紀の後半にあらわれている。「2-0型」は平壌普通門 (1473：図6) 上層ではじめてみられ, 壬辰乱以前の 3 例の「梁 2 型」はすべて「2-0型」であるせ17。

「1-1 型」は内部の手先数が外部よりも多くなる斗栱 の最初の形式であり, 開心寺大雄殿 (1484：図 5) では じめてみられる。また, 壬辰乱以前のもう1つの「手先 数 1 型」の例である長安寺四聖殿 (李朝初) 上層も 「1-1 型」である。さらに壬辰乱の直後-17 世紀はじめ: にもこのような例は多く, 昌慶宮明政殿 $(1616) \cdot$ 慶熙 宮興化門 $(1620) \cdot$ 伝燈寺薬師殿（1621）なぼがある。

この「1-1 型」の斗栱の祖形としては, それ以前から 存在していた「0-0型」と「1-0型」の 2 形式のうち,

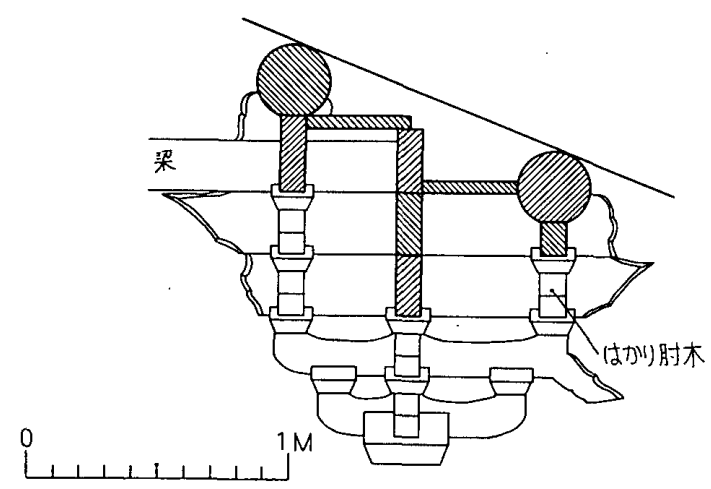

図 6 平壤普通門 上層斗栱 (2-0 型)

(「朝鮮古蹟図譜 十一」挿図をもとに作図) 
䘚 2 梁の位置と手先数の差の組合せによる各斗 栱形式の初見

\begin{tabular}{|c|c|c|}
\hline 形式 & 初 & \\
\hline $0-0$ & 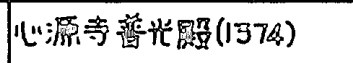 & 国4 \\
\hline $1-0$ & 阙城嫡大门 (1394) & 固2 \\
\hline $2-0$ & 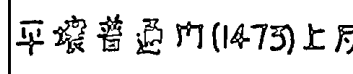 & 圆 6 \\
\hline $1-1$ & 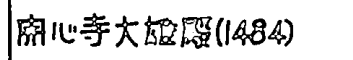 & 国 5 \\
\hline $2-1$ & 昌復客效化门(1608) & 圆 3 \\
\hline $2-2$ & 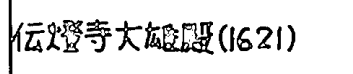 & \\
\hline $0-1$ & 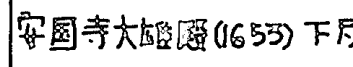 & \\
\hline $0-2$ & 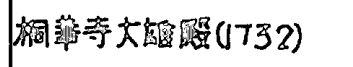 & \\
\hline $1-2$ & 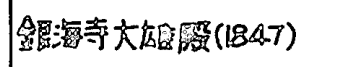 & \\
\hline $1-3$ & 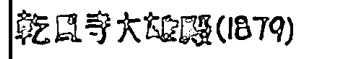 & 军给 \\
\hline
\end{tabular}

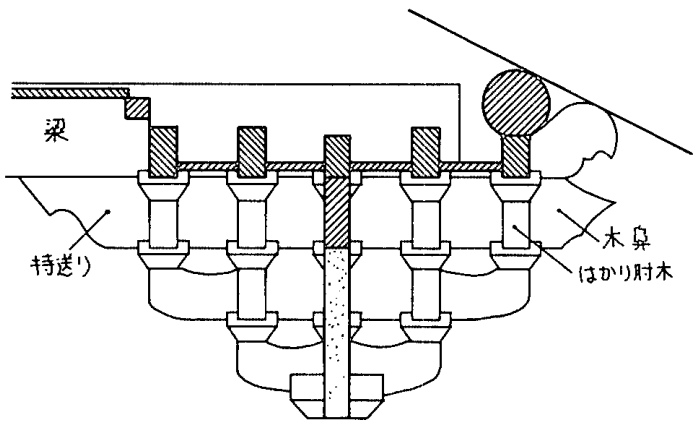

図 7 長安寺四聖殿 下層斗栱 $(1-0$ 型) (修理工事用図面(断面図)をもとに作図)

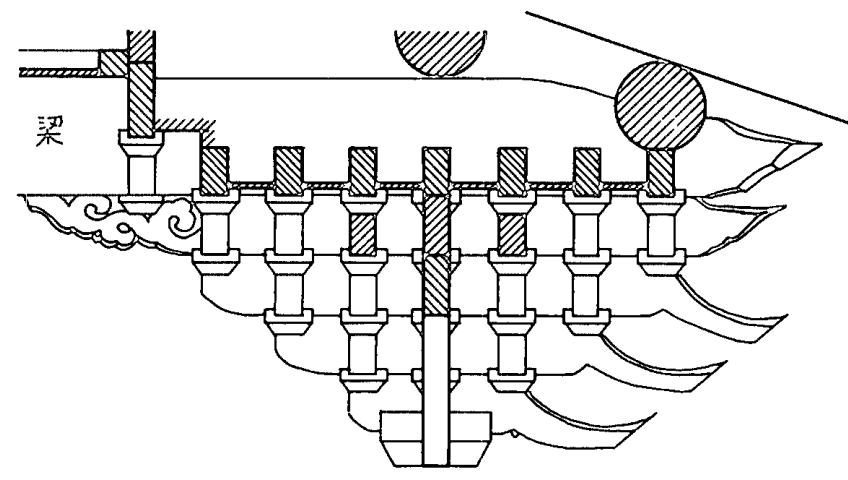

图 8 昌慶宮明政殿 斗栱 (1-1 型)

(『서울(ソウル)特別市史 古蹟篇』所収の断面図をもとに作図)

梁の位置が 「1-1 型」と同じく「梁 1 型」である「1-0 型」 の斗栱が考えられる。柱上斗栱では「1-0 型」には図 2 や図 7 のように外部ではかり肘木と組んで木鼻となり， 内部で梁の持送りとなる材が用いられている。この材の 内部の梁持送りの部分を肘木と同様に扱い斗をのせ，さ らにはかり肘木を設ければ図 $5 ， 8$ のような「1-1 型」 の斗栱となる望18。

さらに変化したものとして「2-1 型」および「2-2 型」
が壬辰乱の後にあらわれる。「2-1 型」は「1-1 型」の斗 栱に再び梁の持送りの材が重ねられて梁の位置が上った 斗栱，ないしは「2-0 型」斗栱の内部の手先数が 1 手先 増した形式とみることができる。「2-1 型」の最初の例 は昌徳宮敦化門 (1608：図 3 ) であり, 青谷寺大雄殿 (1613)・双鉴寺大雄殿（仁祖朝）なぼが早い例である。 なお，前述のように 17 世紀に「梁 2 型」が比較的多く みられるが，これは表 1 より明らかなように「2-0 型」 に加え，この時期にこの「2-1 型」があらわれたためで ある。

「2-2 型」は「2-1 型」斗栱の内部の手先数がもう 1 手 先さらに増して「手先数 2 型」になったものと考えられ る。「2-2 型」は現存する遺構では伝燈寺大雄殿（1621） 1 例だけである。

以上のように, 開心寺大雄殿から伝燈寺大雄殿まで一 時期的には 15 世紀後半から壬辰乱直後の 17 世紀はじめ まで，斗栱形式は「1-0 型」を祖形として「1-1 型」へ， 「1-1 型」· 「2-0 型」から「2-1 型」，さらに「2-2 型」へ と変化したと考えられる。すなわち，梁の位置と内部手 先数の間に関連が認められ，この時期には両者は関係し ながら変化しているといえる。

伝燈寺大雄殿（1621）以降に新たにあらわれる形式は， 以上の変化によってあらわれた形式とは異ったものとな る。すなわち, 表 2 の安国寺大雄殿 (1653)下層の「0-1 型」 以下では, 梁の位置は変らず「梁 0 型」のまま内部の手 先数だけが増したり（「0-1 型」「0-2 型」),「梁 1 型」の ままで内部の手先数が 2 手先， 3 手先多くなる形式 (「1-2 型」「1-3 型」) があらわれる。これらの形式は前 記の伝燈寺大雄殿までの形式とは異なり，梁の位置に関 係なく内部の手先数だけが増す形式である。（写真 1)

これらの形式に属する斗栱は, 安国寺大雄殿下層を除 き, いずれも 18 世紀半ば以降の建物でみられるもので ある。したがって，主として 18 世紀半ば以降に，斗栱 内部の手先数を外部よりも多くすることが，梁の位置と の関係を離れて行われるようになったと考えられる。な お，19 世紀に前述のように「梁 0 型」が 3 例みられるが， これらはいずれも「0-1 型」ないしは「0-2 型」の斗栱 である。

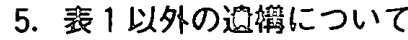

表 1 に挙げた以外の，建築年代を記録頑等で知ること ができなない建物这19の斗栱について梁の位置および内 外の手先数の差を示したものが表 3 である。

まず，「1-0型」となるものであるが，以上の考察で は「1-0 型」は高麗末ないしは李朝の最初期からみられ， 李朝末まで存在している。しかし，もう少し時代笧囲を 狭めれば，「梁 1 型」が広く普及するのが壬辰乱の後で あり 19 世紀以降には「手先数 0 型」の例が減少するこ とから，壬辰乱〜18世紀に一般的な形式といえる。表 
表 1 各遺構の梁の位置と内外手先数の差

\begin{tabular}{|c|c|c|c|c|c|c|c|c|c|c|c|c|c|c|}
\hline 建物名 & 建案年代 & 粱自定 & $\begin{array}{l}\text { 手先 } \\
\text { 外 }\end{array}$ & 望 & $\begin{array}{l}\text { 手先数 } \\
\text { の至 }\end{array}$ & 建智年代の根地 & 典如 & $\mid \begin{array}{l}\text { 長安寺大䃘殿·下 } \\
\text { 松立寺四天王门 }\end{array}$ & & $\begin{array}{l}1 \\
1\end{array}$ & $\begin{array}{ll}3 & 3 \\
2 & 2\end{array}$ & $\begin{array}{l}0 \\
0\end{array}$ & 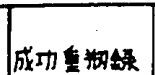 & 0 \\
\hline 敬天寺十寻互唔 & 348 & - & 2 & $=$ & - & 崞名 & 0 & 伐堂寺大咕殿 & & 1 & 3 & 0 & 事路此 & 古 \\
\hline 儿源寺曾光殿 & & 0 & 3 & 3 & 0 & 碑文 & 古.杉 & 双峰手大埋眼三 & 724 & - & - & - & 上樔文 & 古, \\
\hline 䣋王寺庶真殿 & 86 & 0 & 2 & 2 & 0 & (涗野昼) & 古蒗 & & & - & - & - & & \\
\hline 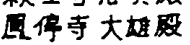 & 高末李初 & 1 & 2 & 2 & 0 & 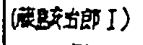 & 0 & - & & - & 3 & 0 & & \\
\hline 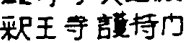 & 1392 & & 2 & & & (用野昼） & 古 & 㸝王寺大姆段 & 1731 & 0 & 5 & 1 & (奥野苫) & 古 \\
\hline 用城南大门 & $\begin{array}{l}1394 \\
1396\end{array}$ & 1 & $\begin{array}{l}1 \\
1\end{array}$ & $\begin{array}{l}1 \\
1\end{array}$ & $\begin{array}{l}0 \\
0\end{array}$ & 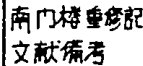 & $\begin{array}{c}\text { 古，肉 } \\
\text { 古 }\end{array}$ & $\begin{array}{l}\text { 柏華寺大婎段 } \\
\text { 松広寺説法堂 }\end{array}$ & & 0 & $\begin{array}{l}3 \\
2\end{array}$ & 2 & 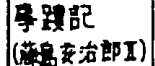 & O \\
\hline ソウル茼大ウ・上 & 1448 & 0 & 3 & 2 & -1 & 世泉实録 & 吉，偍 & 直指寺 大媢殿 & & 1 & $\overline{3}$ & 0 & 重刢䣰 & $\bar{t}$ \\
\hline & & 0 & 2 & 2 & 0 & & & 仁政门 & & 1. & 3 & 1 & 英租舁 & O,t,,-1 \\
\hline 中筧寺址十扈石塔 & 1467 & - & 2 & - & - & 碑全各 & 0 & 仏国寺掹桇殿 & 1750 & $2^{*}$ & 2 & 0 & 事䟲 & 0,14 \\
\hline 平培㗬仁殿 & & 0 & 2 & 2 & 0 & (杉山倨三) & 古 & 视王寺龍升楼 & & & 1 & & (肉里真) & 古 \\
\hline 神勒寺祖 師堂 & 1469 & - & 2 & 2 & 0 & 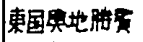 & 0 & 七仙星殿 & & & 3 & & 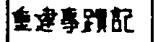 & 古 \\
\hline 平喪普通门・上 & & 2 & 2 & 2 & 0 & 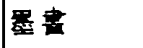 & 古，杉 & 普定寺大堆矩 & 17 & 0 & 5 & 2 & 帚踳記 & 古 \\
\hline & & $\overline{0}$ & 2 & 2 & 0 & & & 大䧸殿 & & 1 & 34 & 1 & 夢復等志。 & 0 \\
\hline 南心寺大婎殿 & 1484 & 1 & 2 & 3 & 1 & 墨茟 & O.杉 & 伀国 & & $2 *$ & 34 & 1 & 專䟲 & O.从 \\
\hline 安辺客舍器楼 & 1486 & 2 & 1 & 1 & 0 & (因野貞) & 古，㭅 & 仏国寺皆要门 & & 2 & 2 & 0 & 䠝 & 0.14 \\
\hline 成仏寺庇真殿新面 & 1530 & 0 & 1 & 1 & 0 & 俥要 & 古，杉 & 棈垔寺大婎跑 & 17 & & 2 & & (周里真) & 古 \\
\hline 清平寺桠煘殿 & 1557 & 0 & 2 & 2 & 0 & 瓦路 & 古，玌 & 龍珠寺大婎殿 & & 1 & 3 & 1 & 影费 & 0 \\
\hline 長安寺四渵股上 & 李初 & 1 & 3 & 4 & 1 & (杉山倌三) & 古 & 水原城長要门・上 & & 0 & 3 & 0 & 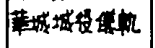 & 古 \\
\hline & & 1 & 2 & 2 & 0 & & & & & 1 & 2 & 1 & & \\
\hline 平㳖大同门·上 & 1576 & 0 & 2 & 2 & 0 & (肉野桌) & 古 & 水原城八莌ウ・上 & 1794 & 0 & 3 & 0 & 茟域城投的 & O, 古 \\
\hline & & 0 & 2 & 2 & 0 & & & & & 1 & 2 & 1 & & \\
\hline 宝林寺大雄殿·下 & 本初 & 2 & $\overline{2}$ & 2 & 0 & 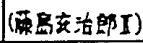 & 古 & 永興本官正殿 & & 1 & 1 & 0 & 正宗 & 古 \\
\hline ソウル文朝大成毁 & 1602 & 1 & 2 & 2 & 0 & 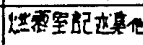 & 0 . & 神勒寺梅等空毁 & & 2 & 3 & 1 & 彭距 & 0 \\
\hline 大向文㡿大成股 & 1605 & 1 & 2 & 2 & 0 & (佃野点) & 0 & 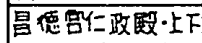 & 1804 & 0 & 34 & 1 & 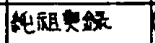 & Q.古,k- \\
\hline 安心寺大雄殿 & 1606 & 1 & 3 & 3 & 0 & 上森文 & 0 & 平塿文神 & & 1 & 2 & 1 & 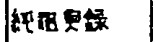 & 古 \\
\hline 昌德犃教化门上下 & 1608 & 2 & 2 & 3 & 1 & 墨書 & O.서 & 大翼寺千仏貶 & 18 & 1 & 34 & 1 & 大䓯寺志 & 0 \\
\hline 青公寺大堆殿 & 16 & 2 & 2 & 3 & 1 & 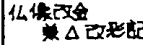 & O.古 & 大興寺大雄聂 & 18 & 1 & 23 & 1 & 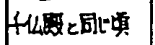 & 0 \\
\hline 昌度宫明政殿 & & $\overline{1}$ & $\overline{3}$ & 4 & 1 & 量雪 & O.古서 & 海印寺大致光毁 & 18 & $i$ & 3 & 1 & 失火踥 & 0 , 古 \\
\hline 甼夏昌明政门 & & $2^{*}$ & 2 & 3 & 1 & 文文献借君 & O.t. & 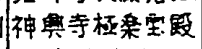 & 18 & 0 & 5 & 2 & 重传上梁文 & 0 \\
\hline 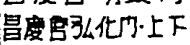 & & 1 & $\overline{2}$ & 3 & 1 & 文献㒂考 & O.t. & 扗㟔寺大婎殿 & 18 & 1 & 34 & $\overline{1}$ & 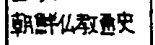 & 0 \\
\hline 知龍寺大堆殿 & & 1 & 2 & 2 & 0 & 上湘丈 & 0 & 重奥寺大碓殷 & & 1 & 23 & 1 & 上梠文 & 古 \\
\hline 总舆化门 & & 1 & $\overline{2}$ & $\overline{3}$ & 1 & 光:海君日㔀 & O,서 & 梁泉寺大埤殿 & & 0 & 23 & 1 & 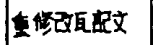 & 古 \\
\hline 妘燎寺大婎殿 & 16 & 2 & 2 & 4 & 2 & 棎间鍵 & O, & 松㕕寺 大雄殿 & & 1 & 4 & 1 & 上棎文 & 古 \\
\hline 伝哣寺菜励段 & 162 & $\overline{1}$ & $\overline{1}$ & 2 & 1 & 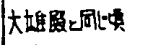 & O.都 & 銀海寺大雄殿 & & 1 & 6 & 2 & 重建部 & 0 \\
\hline 法住手大碓段·上 & & 1 & 3 & 3 & 0 & 上梕丈 & O.古 & 全州爱基 & & 1 & & 0 & 哲泉实领 & O.古 \\
\hline & & $j^{*}$ & 2 & 2 & 0 & & & 全州尊基殿正殿 & & & & 0 & 哲泉零银 & O. 古 \\
\hline 法住寺捍1相殿·五 & 1626 & - & $\overline{3}$ & - & - & 上梠文 & O.古募 & 景禬宫光化内・上F & & 1 & 3 & 1 & 上㗎文 & 古 \\
\hline 金山寺弥鹋厥·三 & & 1 & 2 & 2 & 0 & 金山寺㜊 & O.古 & 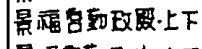 & & 1 & & 1 & 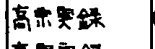 & O,古, \\
\hline & & 1 & 2 & 2 & 0 & & & 景福奋蓝 & & 1 & 2 & 1 & 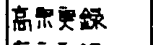 & ○, 古 \\
\hline & & $1^{*}$ & 2 & $\overline{2}$ & 0 & & & 景和 思政䟝 & & 1 & 23 & 1 & 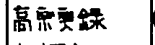 & O.t,서 \\
\hline 金山寺大的殿 & 163.5 & 0 & 3 & 2 & -1 & 金山寺謊 & O,古 & ソテラル東大ウ・上 & & 1 & 33 & 0 & 上梕文 & O古姜 \\
\hline 環城寺 大婎殿 & & 2 & 3 & $\overline{4}$ & 1 & 潇国寺利全書 & 0 & & & 1 & 23 & 1 & & \\
\hline 華确寺大 & 163 & 2 & 3 & 3 & 0 & 大華臀寺䕈 & 0 , 数 & 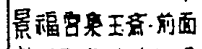 & & 1 & 11 & 0 & 茴息实錻 & 古, A \\
\hline 寺大轮股 & 16 & 2 & 3 & 4 & 1 & 焉兽 & 0 & 乾每寺大雄殿 & & 1 & 36 & 3 & 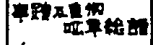 & 古 \\
\hline 宫宣改级 & 1647 & 1 & 2 & 3 & 1 & 修理䂙監倩軌 & 古,서 & 榆跕寺能仁殿 & & 1 & 47 & 3 & 重知部 & 古 \\
\hline 寺大堆即 & 上相転 & 2 & $\overline{3}$ & 4 & 1 & (肉野貞) & 0 & 神溪寺大站殿 & & 1 & 46 & 2 & 重修上榴文 & 古 \\
\hline 硔. & 165 & $\overline{0}$ & 3 & 4 & 1 & (周野貞) & 古 & 德寿兑中和门 & & 1 & 23 & 1 & 高宗里银 & 0 \\
\hline 篗殿 & 1660 & 1 & 3 & 4 & 1 & & 古 & 德寿害中和殿 & & 1 & 34 & 1 & 高尔粮 & O., \\
\hline 寺桠条賏·的面 & 順治年间 & 1 & 1 & 2 & 1 & & 古 & \multirow{13}{*}{\multicolumn{7}{|c|}{ 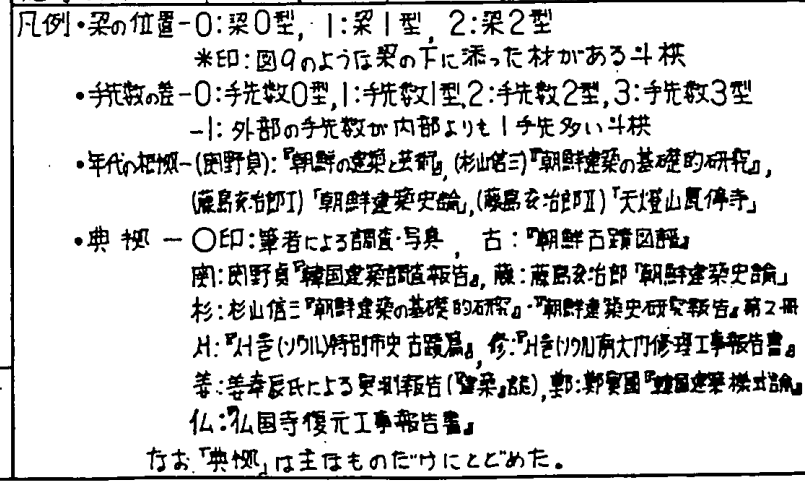 }} \\
\hline 寺大蒙殿 & 1670 & 2 & 2 & 2 & 0 & 事早 & 0 & & & & & & & \\
\hline 寺大瞧殿 & 1676 & $\overline{1}$ & 3 & 4 & 1 & 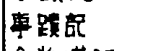 & 古，宛 & & & & & & & \\
\hline 寺大雄䟝 & 16 & 2 & 3 & 4 & 1 & 金堂塔䄫 & 0 & & & & & & & \\
\hline 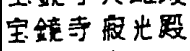 & 1677 & 1 & 2 & 2 & 0 & 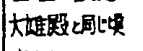 & 0 & & & & & & & \\
\hline 寺普光殿 & 1678 & & 2 & & & 事跣 & 古 & & & & & & & \\
\hline 楚魚寺大堆殿 & 1680 & 2 & 3 & 4 & 1 & (医野貞) & 0 & & & & & & & \\
\hline 禅票寺大媸殿 & 1682 & 1 & 3 & 3 & 0 & 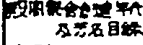 & $\mathrm{O}$ & & & & & & & \\
\hline 藇国寺大坥旪 & 1690 & 2 & 3 & 3 & 0 & 事踪 & 0 & & & & & & & \\
\hline 影浪夺大堆役 & 17 t妃 & 1 & 2 & 2 & 0 & 再鼓 & 0 & & & & & & & \\
\hline 華敏寺党皇展·上下 & 1701 & 2 & 2 & 2 & 0 & 大華得寺婄 & O. & & & & & & & \\
\hline 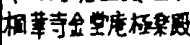 & & $\overline{1}$ & 2 & 2 & 0 & 事䠝䛕 & 0 & & & & & & & \\
\hline 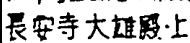 & & $i^{*}$ & 3 & 4 & 1 & 上槡文 & 古 & & & & & & & \\
\hline
\end{tabular}


表 3 建築年代不明の遗構の斗栱形式

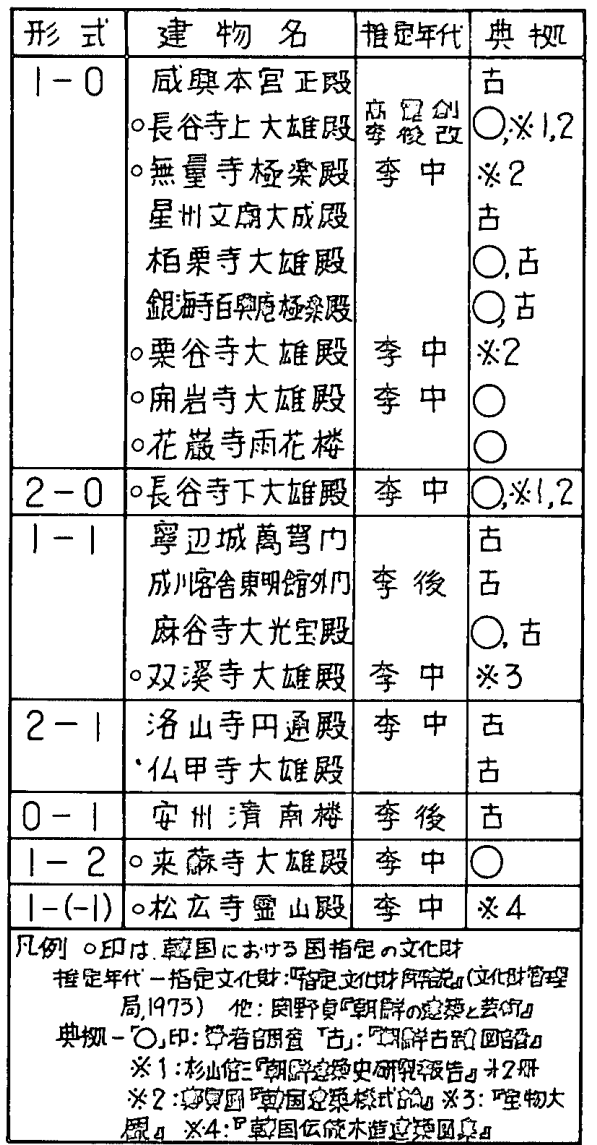

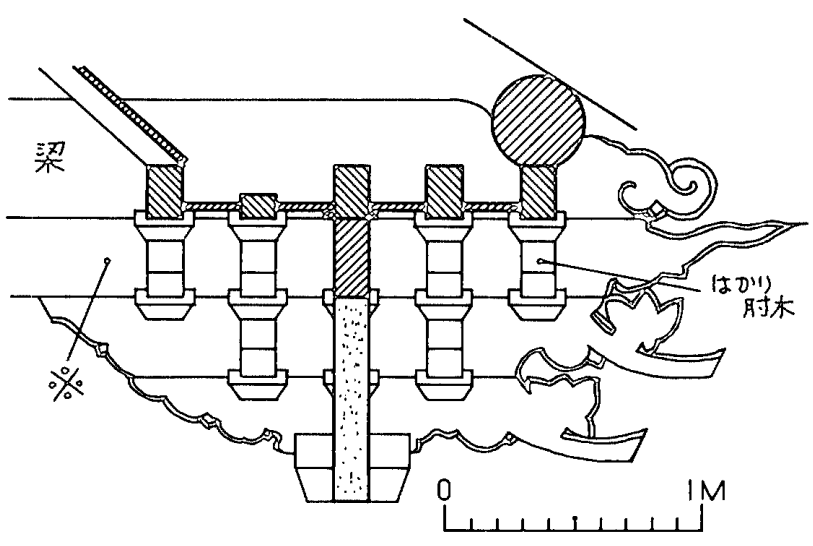

図 9 金山寺弥勒殷 初層斗栱

（韓国文化財管理局 補修工事用図面をもとに作図）

3 の「李朝中期」とされる建物はこの時期と重っており, 他の多くもこの時期の建物であろう。「高麗創・李朝後 期改建」とされる長谷寺上大雄殿は高麗創建時の材を残 しながらもほとんど再建に近い改建を「李朝後期」にな された建物である此。

次に,「2-0 型」の長谷寺下大雄殿であるが，「2-0 型」 は表 1 より 15 世紀後半〜18 世紀に行われており，推定 された「李朝中期」と一致する。

「1-1 型」は 15 世紀後半からみられるが, 「手先数 1 型」 の普及が壬辰乱以後であることを考虑すれば壬辰乱以降 の建物である可能性が高い。推定された「䆘朝中期」「李
朝後期」と一致する。

また，「2-1 型」は壬辰乱より後にあらわれる形式で あり,この 2 楎は壬辰乱以後の建物であると考えられる。

「0-1 型」の安州清南楼と「1-2 型」の来蘇寺大雄殿は, ともに梁の位置との関係を離れて内部の手先数だけが增 加する形式と本稿でした形式であり，この形式は 18 世 紀半ば以降に主として行われる。上記 2 標のうち来蘇寺 大雄殿は「䆘朝中期」の建物と推定されており,これが 正しいとすれば梁の位置との関係を離れて内部の手先数 だけが増加する形式としては安国寺大雄殿（1653）下層 とともに早い例である。

松広寺霊山殿は, 内部の手先数が外部よりも少い斗栱 でこのような斗栱は他にソウル南大門 (1448) 上層・ 金山寺大寂光殿（1635）でみられる。しかし，両建物と も「梁 0 型」であるのに対し, 松広寺霊山殿では「梁 1 型」 となっており，他にはみられない形式である。

6. 結

多包系建築の斗栱を梁の位置と内外手先数の差からみ たとき，高麗末ないし李朝の最初期からみられる古い形 式は「梁 0 型」または「梁 1 型」で「手先数 0 型」のも のである。

この形式に変化がみられるのは 15 世紀後半からであ り，斗栱内部の手先数を外部よりも多くすること（「手 先数 1 型」) が行われはじめる。また，「梁 2 型」もこの 時期からみられる。

次に壬辰乱を境として変化がみられる。内部手先数が 外部より多い「手先数 1 型」が壬辰乱を境として広く普 及し，また「手先数 2 型」もあらわれる。同時に，これ 以前には少数であった「梁 1 型」が広く行われるように なり，逆に「梁 0 型」が減少するのもこの時期である。 すなわち, 李朝末の一般的な形式がこの時期を境に広く 普及した。

また, 15 世紀後半から壬辰乱後の 17 世紀はじめまで は, 内部の手先数の増加と梁の位置が関係しながら斗栱 形式が変化していると考えられるのに対し，18 世紀半 ば以降にみられる形式では梁の位置とは関係なく内部の 手先数を增す手法がみられる。また，古くからの形式で ある「手先数 0 型」がほとんゼみられなくなり，内部の 手先数が外部よりも多い斗栱が一般的になるのも 19 世 紀以降のことである。

このような変遷を経てみられるようになる㞭朝末の斗 栱は,「梁 1 型」で内部の手先数が外部よりも多い形式 であり, 内部の手先数を 2 手先 $\cdot 3$ 手先多くする際に梁 の位置とは関係なく增すような斗栱である。

\section{注}

1) 藤島亥治郎「朝鮮建築史論 其五」(『建築雑誌」536 号, 昭和 5 年 8 月) で最初に示され，その後一般化している。 なお，韓国ではこの両様式に加え，疎組で前後に手先を 
持ち出さない斗栱を用いる建物を「翼工系(式)としてさ らに区別することが多い。

2）藤島亥治郎前掲論文では「唐様系建築」，杉山信三「朝鮮 建築の基礎的研究」(昭和 23 年, 私家版) および「朝鮮 建築史研究報告」（昭和 $24 \cdot 25$ 年，私家版）では「唐様」 とし，関口欣也「高麗末李朝前期における詰組系様式の 系統」(「仏教芸術」113 号, 昭和 52 年 6 月) では「詰組 系様式」としている。また，韓国では尹張炇「韓国建築史」 (1974 年, 東明社)で「多包式」, 鄭寅國「韓国建築様式論」 (1974 年, 一志社)では「多包系」としており，その他「多 包面」(「多包建物」) ともされる。共和国では朝鮮科学院 歴史研究所編【조선문화사】(「朝鮮文化史」1977 年) で「포 식（包式)」としている。

3）古くは関野貞「釈王寺」(「朝鮮の建築と芸術」昭和 16 年, 岩波書店所収）で採王寺応真殿（1386）について元建築 の影響を指摘しており，最近では関口欣也前揭諭文で詳 細に検討されている。

4）杉山信三「唐様の研究」(「朝鮮建築史研究報告」第 2 冊) $\lceil\cdots$ 元風をうけついだ建築は，…(中略）…との特色を斗 栱にあらはして，その変遷は肘木，木鼻の些少な点に指 示することが出来, それと絵様を増して複雑ならんとす る傾向は，そこに最も当を得た場を見出せるもの〉如く， それを，建築によってみる朝鮮風なものとしやう。…」 尹張炇 前掍青 p. 232

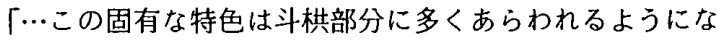
り，その外形の整斉化, 細部手法の造形意匠的な発展お よび多様化などにみることができる。(筆者訳)

5) 时木に造り出した尾垂木形。仮搨。

6)藤島亥治郎「朝鮮建築史論 其五】(『建築雑誌」536 号, 昭和 5 年 8 月)

杉山信三「朝鮮建築の基礎的研究」(昭和 23 年, 私家版) および「朝鮮建築史研究報告】(昭和 $24 \cdot 25$ 年, 私家版) 尹張炇『韓国建築史」(1974 年, 東明社)

鄭寅國「韓国建築様式論」(1974 年, 一志社)

金正基「韓国木造建築」(1980 年, 一志社)

関口欣也「高麗末李朝前期における詰組系様式の系統」 (『伀教芸術」113 号, 昭和 52 年 6 月)

なお，韓国におけるものはいずれも通史であるが，管見 では多包系建築の斗栱形式の変遷を問題の中心とした論 文はみられない。また，共和国では前掲の【조선문화사」 (「朝鮮文化史」) があるが, 斗栱形式の変遷にはほとんど 触れていない。

7）韓国における用語に従った。

8）関野 貞「韓国建築調查報告」(明治 37 年, 東京帝国大学) p. 249

$\lceil\cdots$ 特二後期清朝卜疎隔セルニ及ヒテハ益彼ヨリ独立シテ 固有ノ特質 尹発展シタリ者ノ如シ…(中略) …頗支那) 様式卜面目 7 異二シ亦我国二於ヶル者トモ大ナル差違了 ルコトヨ見ルナリ」
9）たとえば，柱上斗栱外部の木鼻のうち梁頭が突出する位 置に関係する。拙稿「朝鮮多包系建築の「梁頭形木鼻」 について」(昭和 59 年度建築学会大会) 参照。

10.) 杉山信三「朝鮮建築の基礎的研究」p. 76 に

$\lceil\cdots$ 尚手先の数が内と外と異ってるるのは, 即ち内部の斗 栱の手先を一つだけ深くよる工夫は当期（李朝初期一筆 者）も終りになって来てあらはれたものである。手先が, 内部に於いて特に深くすることは，棰匂配に伴了丸析の 位置が決定せることで，そこに華盤をいれる方法もあら うがこの手法にもよられたことを知るのである。」

とあり，尹張炇 前揭書 p. 233 にも同様の指摘がある。

11）先学による研究, 上樑文等の記録によって建築年代を知 ることができるものとした。しかし, 主として 17 世紀後 半以降の建物では研究・調查が不十分な建物があり, こ れらについては筆者が記録類から建築年代を判断した。

12）斗栱内部では後述するような手先数の増加がみられるた め, 梁の位置を示す上での基準を設けにくい。

13）多包系建築の祖形と考えられている元の建築でもはかり 肘木より1段上に梁がある例がみられる。たとえば, 永 楽宮三清殿・重陽殿前面 $(1244 \sim 62)$ ・青龍寺大殿 (1350) 前面など。

14）重層以上の建物の場合, 各首で斗栱の形式に違いがある ときには別々に数え，全く同形のものは 1 例として数え た。以下も同じ。

15） 17 世紀前半の「梁 1 型」のなかには，図 9 のように梁に 添って※印をした材をはかり时木の位置に用いている例 が法住寺大雄殿（1624）下層・金山寺弥勒殿（1635）初 層でみられる。

16）注 10 参照。

17）「2-0型」は「1-0 型」の梁がもう1段上に組まれた斗栱 と考えられる。しかし，詳細にみると壬辰乱以前の「2-0 型」のうち平㙵普通門 (1473) 上層 (図6) と安辺客舎 駕鶴楼（1486）では，斗栱内部に中借斗栱と同形の三角 形の木鼻が用いられており, 壬辰乱以前の「2-0 型」に ついては,なお検討の余地がある。

18）中備斗栱に関しては，柱上斗栱に従って変化したものと 考えられる。また, 中備斗栱では「0-0 型」も「1-0 型」 も差はなく,どちらを「1-1型」の祖形ということはで きない。

19）韓国における指定文化財および「朝鮮古蹟図㬐】所収の 多包系建築の遗構。指定文化財のうち松広寺薬師殿 (李中) は桁行 1 間の建物で建物内部に梁があらわれないため (「手先数 1 型」), 花繁寺極楽殿は尾垂木を用いる特殊な 形式の斗栱であるため，また威鳳寺普光明殿（「手先数 0 型」）と仏影寺応真殿は詳細が不明なため, それぞれ除い た。

20）杉山信三「朝鮮建築の基礎的研究」によれば，大斗，大 斗と組むはかり肘木, 中備斗栱, 柱の一部, 妻の大虹梁 が古い材とされる。 


\section{SYNOPSIS}

UDC : 72. 032(519) : 69.02

ON THE EVOLUTION OF BRACKETING COMPLEX OF THE TAP'O-STYLE ARCHITECTURE IN KOREA, UPON ANALYSIS OF THE POSITION OF

BEAMS PUT IN THE BRACKETING AND THE INCREASE OF THE NUMBER OF STEPS OF THE BRACKETING INSIDE THE BUILDING

by AKIRA NAKANISHI, Research Student of Tokyo Institute of Technology, Member of A.I.J.

It is essential to study the position of beams put in the bracketing and the increase of the number of steps of the bracketing inside the building, in order to systematically prove the changing process of bracketing complex in the Tap'o-style architecture in Korea. The present paper is to inquire into the evolution of bracketing from above-mentioned points of view.

In the old type of bracketing during the period between the late Koryo-Dynasty and the early Yi-Dynasty, the number of steps of the bracketing inside the building is equal to that of the outside (Figs. 1,2). From the latter half of the 15 th century, this type of bracketing changed into a new type : the number of steps of the interior bracketing is more than that of the exterior bracketing. This is due to the position of the beams put in the bracketing.

After the second half of the 18 th century, the increase the number of steps of the interior bracketing has no relation to the position of beams (phot. 1). Thus, this type is regarded as one of the characteristics in the Tap'o-style at the end of the Yi-Dynasty. 